IMMIGRATION AND THE QUALITY

OF JOBS

Daniel S. Hamermesh

Working Paper 6195 


\section{IMMIGRATION AND THE QUALITY OF JOBS}

Daniel S. Hamermesh

Working Paper 6195

http://www.nber.org/papers/w6195

\section{NATIONAL BUREAU OF ECONOMIC RESEARCH 1050 Massachusetts Avenue \\ Cambridge, MA 02138 \\ September 1997}

I thank Frank Bean, Stephen Bronars, Edward Montgomery, Melissa Famulari, and participants in seminars at several universities for helpful comments during the development of this project, and Cynthia Zoghi for her excellent research assistance. Research support for this study was provided by a grant from the Mellon Foundation and by the National Science Foundation under grant SBR9422429. This paper is part of NBER's research program in Labor Studies. Any opinions expressed are those of the author and not those of the National Bureau of Economic Research.

(C) 1997 by Daniel S. Hamermesh. All rights reserved. Short sections of text, not to exceed two paragraphs, may be quoted without explicit permission provided that full credit, including (C) notice, is given to the source. 
Immigration and the Quality of Jobs

Daniel S. Hamermesh

NBER Working Paper No. 6195

September 1997

JEL Nos. J61, J23

Labor Studies

\begin{abstract}
A precondition for the absence of labor-market competition between immigrants and natives is that they differ in their willingness to accept work that offers different amenities. The implications of a model embodying this assumption are that immigrants will be observed experiencing inferior workplace amenities than natives, and that the presence of immigrants will affect the amenities natives enjoy. I examine these possibilities on three sets of household data: The merged May and June 1991 Current Population Surveys, giving information on the timing of work over the day by nativity; the June 1991 CPS merged with industry data on workplace injury rates and durations; and the Quality of American Life Surveys of 1971 and 1978, providing workers' responses about their satisfaction with particular aspects of their jobs. The analysis clearly shows that observationally similar immigrants and native whites enjoy very similar packages of amenities: The precondition for noncompetition between immigrants and natives does not exist. Also, a greater immigrant concentration has no consistent effect on the amenities natives enjoy. African-Americans, however, receive a set of workplace amenities that is inferior to that of otherwise similar native whites and immigrants.
\end{abstract}

Daniel S. Hamermesh

Department of Economics

University of Texas

Austin, TX 78712-1173

and NBER

hamermes@eco.utexas.edu 
"I can't hire all legal people. Who wants to work in this dirty job? American people? No." Jane Lee, whose Manhattan firm, Jane Productions, was raided by the Immigration and Naturalization Service. New York Times, June 3, 1996, page A1.

\section{Introduction}

Perhaps the most common argument in favor of immigration is that "immigrant workers are in jobs rejected by indigenous workers." (Castles and Kosack, 1973, p. 112) This idea, that immigrants are welcome because they take jobs that natives would not take, and thus that would otherwise not be performed, underlies some academic discussion (Piore, 1979). It is also much in (at least part of) the popular mind. For example, in discussing their migration to Germany from the former Soviet Union, the ethnic German returnees stated that, "...their children wanted to work, even with jobs other Germans will not look at."1

It is not clear from either the academic discussion or popular sentiment what mechanism underlies the behavior implicit in these views. I do not believe that it is simply that immigrants will work for lower wages than otherwise identical natives. If that were the case, however, it would be difficult to see how the displacement of at least some very low-wage native workers could be avoided, especially in the presence of a binding minimum wage. It might be, as Piore (1979) implies, that employers create special "immigrant jobs" that would not otherwise exist; but without the immigrants themselves having preferences about jobs, and without some underlying supply behavior, treating them as passive tools of exploitative employers is both belittling and probably wrong.

I interpret the popular and academic suggestions as implying that immigrants are not simply workers who are willing to accept lower wages than natives. They may even have the same skills as natives; but they are more willing to take jobs that offer nonpecuniary aspects of work that natives find unacceptable. This view allows us to explore the extent of workplace disamenities faced by immigrants, as opposed to natives, particularly low-skilled and minority natives.

Examining workplace amenities faced by immigrants, low-skilled and minority natives, and other natives can provide the basis for evaluating the burgeoning literature on employment substitution between 
immigrants and natives. While a number of studies suggested that the extent of substitution is small (see the summary in Hamermesh, 1993, Table 3.10), more recent work (Borjas et al, 1996; Haisken-de New and Zimmermann, 1996; Reimers, this volume) is increasingly conflicted on this issue. All of these studies categorize workers by location of birth and/or ethnicity and assume that workers in these categories form different groups in the labor market. While this artificial distinction, so prevalent in the literature, is convenient and may make sense, it is quite arbitrary and perhaps inconsistent with a more appropriate aggregation based on the skills embodied in the groups. ${ }^{2}$ By studying how amenities differ among these groups, in this research we can go beyond the standard approach and discover to what extent it is logically possible for the different groups to compete in the labor market.

This study should be viewed as a belated precursor to the large literature on immigrant-native labormarket competition, since it lays out the mechanism by which such substitution might arise and presents a variety of evidence on whether that mechanism is important in the United States. I first consider how an influx of immigrants might affect the workplace disamenities enjoyed by low-skilled workers and the effect on the average level of amenities faced by all low-skilled workers, immigrants included. Section III describes the several sets of data used to examine these issues and the particular amenities on which this study focuses. In Section IV I then compare the average extent of various amenities enjoyed by immigrant and native workers, while Section V tests the model of Section II directly by examining how a greater presence of immigrants affects the degree of two of the disamenities I consider, working at unpleasant times and the risk of on-the-job injury, experienced by workers in the native population.

\section{Inferring the Effect of Immigration on Workplace Disamenities}

We wish to infer how the addition of a group of immigrants will affect the average level of workplace amenities and, even more important, the amenities enjoyed by native workers, particularly low-skilled workers. Building a model that imposes substitution possibilities directly in a production function would have the same faults -- mainly that of arbitrarily assuming that substitution will exist -- that are present in the literature on 
job competition between immigrants and natives. I specify instead a very simple model that allows no direct substitution between natives and workers in production. Rather, it relies on product-market clearing and the entry and exit of firms to generate results on both immigrant-native substitution and on the pattern of workplace disamenities in the economy. The general idea in the model is to examine the implications for the amenities enjoyed by natives if immigrants' willingness to accept disamenities differs from that of natives. Thus it captures the underlying behavior that seems implicit in the notion of immigrants accepting jobs that natives will not take.

Consider first what wages and the distribution of disamenities will look like in the absence of immigrants whose tastes differ from natives'. Assume that native workers are homogeneous and derive utility from their jobs depending on the wage rate $w^{j}$ received at firm $j$ and on $\theta^{j}$, the level of the disamenity associated with work at firm $\mathbf{j}$. The typical worker's indirect utility is then:

$$
V=V\left(w^{j}, \theta^{j}\right) \text {, }
$$

where $V_{1}>0, V_{2}<0$, and $V_{11}<0, V_{22}<0$. The signs of the first and second derivatives are based on the notion that workers have increasing marginal rates of substitution of wages for workplace disamenities as the degree of the disamenities increases. I also assume that native workers have some reservation utility, $\mathrm{V}^{\mathrm{N}}$, below which they will not work in the labor market. Presumably this reservation utility is supported by the value of their household production (or perhaps too by the magnitude of governmental or other income transfers).

Assume that all firms sell the same product at a price P. Firms and potential firms are distinguished from each other by a fixed $\theta^{j}$ associated with the firm, which is its particular immutable level of the disamenity. A firm is organized by one person, who is either running a firm or not economically active. Workers cannot organize firms, and entrepreneurs cannot be workers. Each firm employs either one worker, if it produces, or no workers, if it does not produce. If firm $\mathrm{j}$ produces, its profits are:

$$
\pi=P \theta^{j}-w^{j}
$$


where $V_{1}>0, V_{2}<0$, and $V_{11}<0, V_{22}<0$. The signs of the first and second derivatives are based on the notion that workers have increasing marginal rates of substitution of wages for workplace disamenities as the degree of the disamenities increases. I also assume that native workers have some reservation utility, $\mathrm{V}^{\mathrm{N}}$, below which they will not work in the labor market. Presumably this reservation utility is supported by the value of their household production (or perhaps too by the magnitude of governmental or other income transfers).

Assume that all firms sell the same product at a price $\mathrm{P}$. Firms and potential firms are distinguished from each other by a fixed $\theta^{\mathrm{j}}$ associated with the firm, which is its particular immutable level of the disamenity. A firm is organized by one person, who is either running a firm or not economically active. Workers cannot organize firms, and entrepreneurs cannot be workers. Each firm employs either one worker, if it produces, or no workers, if it does not produce. If firm $\mathrm{j}$ produces, its profits are:

$$
\pi=P \theta^{\mathbf{j}}-\mathbf{w}^{\mathbf{j}}
$$

Firms with higher values of the disamenity can produce more goods at the same wage rate as those whose workplaces are safer, cleaner, etc. Firms and potential firms can be viewed as being arrayed from the lowest value of $\theta$, at firm 1 , to its highest value, at firm $J$.

Workers spend their entire incomes (which by assumption equal their earnings) on the product of these firms, as do active entrepreneurs, so that:

$$
\sum_{j=1}^{j N}\left[w^{j}+\pi^{j}\right]=\underset{j=1}{P \sum^{N}} \theta^{j} .
$$

The marginal firm, $\mathrm{J}^{\mathrm{N}}$, is making zero profits in equilibrium in the product market, so that:

$$
\pi^{J^{N}}=P \theta^{J^{N}}-w^{J^{N}}=0
$$


In labor-market equilibrium the worker at this firm is enjoying utility:

$$
\mathrm{V}^{\mathrm{N}}=\mathrm{V}\left(\mathrm{w}^{\mathrm{N}}, \theta^{\mathrm{N}}\right)=\mathrm{V}^{\mathrm{N}}
$$

Because of the assumptions about the nature of workers' preferences, $V$, any firm indexed $j>J^{\mathrm{N}}$ would earn negative profits if it produced, since the cost savings that it could obtain from having a higher value of $\theta$ would be more than offset by the higher wage that it would have to pay to induce a worker to accept the level of the disamenity that it offers, $\theta^{\mathrm{i}}>\theta^{\mathrm{J}^{\mathrm{N}}}$. Taken together equations (3)-(5) determine the endogenous variables in this system: $\mathrm{J}^{\mathrm{N}}$, the identity of the marginal firm; $\mathbf{P}^{*}$, the equilibrium product price; and $w^{\mathrm{J}^{\mathrm{N}}}$, the wage rate at the marginal firm (and hence wage rates at each firm, since all workers receive utility equal to their reservation utility $\mathrm{V}^{\mathrm{N}}$ ).

In the absence of immigrants native workers will be employed at all firms that provide a level of disamenities no worse than some endogenously determined amount. The number of active entrepreneurs is determined by the distribution of amenities and the workers' reservation utility. Among native workers those employed at firms offering a worse set of disamenities will receive a compensating wage differential for the risk of the potential suffering that they face.

Consider what happens in this economy if a fixed number, I, of immigrants enters the labor market. I assume that immigrants are homogeneous and have the identical skills (same education, etc., as natives), but that unlike natives they are unconcerned about the presence of disamenities. ${ }^{3}$ Thus each immigrant will work if he or she can obtain indirect utility:

$$
V=V\left(w^{j}\right) \geq V^{1},
$$

a condition that defines the wage of immigrants, $w^{I}$. This assumption about immigrants' utility is extreme, but the difference between (1) and (6) does capture the notion, implicit in the epigraph to 
this study, that immigrants might take jobs that have such severe disamenties that no native would accept them.

The assumption that avoiding reductions in workplace disamenities enables a firm to produce more cheaply with workers of the same cost guarantees that immigrants will take jobs at those firms with the highest $\theta^{j}$, since the potential entrepreneurs who enter the market in response to immigration can offer the immigrants a higher $w^{\mathbb{J}}$ and still make larger profits than potential firms with a lower index $\mathrm{j}$. The first immigrant worker will thus be matched with the entrepreneur who opens firm $\mathrm{J}$, the establishment with the worst disamenities; as more immigrants enter, more firms open up with successively lower indexes $\mathrm{j}<\mathrm{J}$. There is some firm type $\mathrm{J}^{\mathrm{I}}$ that is the marginal one among those employing immigrants. (Even this firm is making positive profits: In this model sweatshops are quite profitable.) The marginal (zero-profit) firm is the highest- $\theta$ surviving firm that employs native workers.

With the influx of immigrant workers the spending-revenue equality becomes (since we must add the immigrants' production and the demand for output by them and by the entrepreneurs who "accommodated" them):

$$
\sum_{j=1}^{j N}\left[w^{j}+\pi^{j}\right]+\sum_{j=J l}^{J}\left[I w^{I}+\pi^{j}\right]=\underset{j=1}{P \sum^{N}} \theta^{j}+\underset{j=J^{I}}{P \sum} \theta^{j} .
$$

Conditions (4) and (5) must also be satisfied at the new equilibrium, as must (6). This set of conditions generates a new set of equilibrium values of the product price, $\mathrm{P}^{*}$, the marginal firm, $\mathrm{J}^{\mathrm{N}}$, the wage rate of the native worker at firm $\mathrm{J}^{\mathrm{N}}, \mathrm{w}^{\mathrm{J}^{\mathrm{N}}}$, and $\mathrm{J}^{\mathrm{I}}$. This last, the identity of the lowest $\theta$ firm employing immigrants, is trivially determined by the exogenous number of immigrants who have entered the labor market. What happens to $\mathrm{P}^{*}$ and $\mathrm{J}^{\mathrm{N}}$ depends on the assumptions that we make about 
how the new (sweatshop-owning) entrepreneurs spend the large profits that they make. If we make the reasonable assumption that immigrants consume less than native workers, but assume that the profits of sweatshop owners disappear into a black hole, the sweatshops' output then competes with that of firms employing native workers. It drives down the product price and reduces the number of profitable firms that employ native workers. In this case the level of disamenities suffered by native workers decreases on average, as does their wage, along with the decrease in native employment.

More sensibly, at the very least it seems reasonable to assume that spending by the new entrepreneurs does not reduce $\mathrm{P}^{*}$, so that $\mathrm{J}^{\mathrm{N}}$, and thus the wage rate and the disamenities faced by the marginal native worker, remain unchanged. Thus the influx of immigrants raises the overall standard of living among natives by allowing the scope for some entrepreneurs to open up new firms.

Going even further, an alternative assumption is that, with higher average entrepreneurial incomes the consumption demand of entrepreneurs increases, leading to an increase in $\mathrm{P}^{*}$. That in turn makes it profitable for firm $\mathrm{J}^{\mathrm{N}+1}$ to open up, implying an increase in native employment, a higher native wage and worse amenities at the marginal firm (and worse amenities on average among native workers). The average level of disamenities economywide rises: Immigration has allowed the opening of jobs offering a higher rate of disamenities, both in sweatshops and in the marginal firms employing natives whose operations have become profitable.

This simple general-equilibrium model has led to two surprising conclusions: 1) Immigrants who do not mind disamenities will take jobs offering the worst possible set of disamenities; and 2) The average disamenity level in jobs filled by natives may be increased by immigration. Also, even though I assume there is no possibility for substituting immigrants for natives, the dynamics of the product market may make it appear that the influx of immigrants changes natives' job opportunities. 
This entire discussion has treated the native group as homogeneous. This is clearly an oversimplification. In particular, low-skilled workers, and those minorities who face labor-market discrimination, are more likely to be located in the firms that were offering the worst package of amenities before the immigration occurred. With an influx of immigrants the low-skilled (and/or minority) natives who are in jobs with the most severe disamenities may face competition from immigrants who are more willing to take jobs in firms that can be profitable only if they offer still worse disamenities. To the extent that the influx of immigrants does reduce native employment, it will do so especially among low-skilled workers. Alternatively, if it generates positive spillovers onto native workers' employment, those too will be greatest among less-skilled native workers.

\section{Hypotheses About Amenities, and the Data to Test Them}

The theory in the previous section makes it clear that an influx of migrants can affect the wages and amenities of native workers even if there is no direct substitution in the labor market, for the immigration may alter the identity of the marginal firm employing native workers through its effects on product demand. Employment opportunities of natives may change even though we have assumed that there is no labor-market competition. But is that assumption of no labor-market competition correct? Do we really need to go beyond the labor market to provide an explanation for the possibility that immigrants affect natives' wages and employment, or can we find labor-market evidence that demonstrates that the essential assumption of the model -- that "immigrants take jobs that natives won't take" -- is incorrect?

If immigrants are not competing directly with natives for jobs, we will observe that the immigrants are in jobs that offer distinctly inferior amenities to those offered in jobs held by otherwise identical natives. Both groups face the same market-determined trade-off between wages and 
amenities, so that it would make little sense to examine whether compensating wage differentials facing the two groups differ; but if immigrants' willingness to accept disamenities differs from that of natives, we will observe immigrants working in jobs that offer a worse package of amenities given the workers' characteristics. Thus the main order of business is to examine whether some identifiable amenities differ between immigrant and native workers, and, in particular, between immigrants and otherwise identical low-skilled or minority workers. This could be done using household data on amenities related to workers' characteristics (as I do below); or, if we had establishment data, we could test that and the additional implication of the model that workers would be segregated by immigrant status due to employers' inability to assign different amenities to different workers in the same workplace. ${ }^{4}$

Even if the amenities enjoyed by otherwise identical natives and immigrants differ, such differences say nothing about causation. The second question is thus whether an influx of immigrants itself generates any change in the amenities in natives' jobs. The appropriate test of this issue should involve examining how natives' amenities, especially those of minorities, differ depending on the importance of the immigrant population in the labor force.

The main difficulty in performing these tests is the paucity of sets of data that contain information on large arrays of workplace amenities, that do so for large samples of workers (so that a reasonably large number of immigrants is present in the sample), and that identify workers' nativity. This problem severely restricts our ability to examine these ideas empirically and confines the analyses for the United States to three sets of micro data.

The first and best source of data for testing the ideas on this issue results from a fortuitous coincidence. In May 1991 the Current Population Survey (CPS) Multiple Jobholder Supplement 
obtained information on the starting and ending times of a worker's main job. In June 1991 the CPS contained a Supplement on immigrants, including questions on date of migration and country of nativity. Because three-fourths of the respondents were in both the May and June 1991 surveys, I can combine the two surveys to form a data set that has information on immigrant status and, with some manipulation, on whether each respondent is at work at each particular hour. I have shown elsewhere (Hamermesh, 1996b) that work in the evening and at night is a disamenity: Workers with lower full incomes, other things equal, are more likely to be at work at those times. Since we can identify evening and night work as a disamenity, examining differences between immigrants and natives in the propensity to work at those times provides a test of whether the preconditions for immigrant-native labor-labor substitution are absent. The usual CPS demographic measures, including variables representing age, education, marital status, presence of a child under age 6 , location in the "Rust Belt" (the New England, mid-Atlantic or East North Central states), and metropolitan area size (greater than 2.5 million people, between 0.5 and 2.5 million people, less than 0.5 million people, with nonmetropolitan location the excluded group), can also be generated. ${ }^{5}$

The second source of data is the June 1991 CPS itself. Taking the entire sample we can merge workers using their industrial affiliation (3-digit Census code, linked to the 1987 SIC codes) with published information on injury rates per 100 employees and the number of lost workdays per 100 employees (BLS, 1990). Dividing the latter by the former yields the average duration (in days) of lost workday injuries. All the control variables that were generated for the study of work timing using the May 1991 CPS are generated for the examination of injuries. The link between the injury data and the June CPS industry code is not always clear, so that to avoid introducing errors in the crucial variable I discard nearly 10 percent of workers from the original June 1991 CPS sample. ${ }^{6}$ 
The 1971 and 1978 Quality of American Life (QAL) surveys identify immigrants (country of birth, actually) and provide information on the respondents' parents' nativity. Pooling the samples for the two years yields a sufficiently large number of usable observations and thus provides a third sample that offers some hope of identifying differences between natives and immigrants. From the survey information I generate indicator variables for educational attainment, race, the size of the metropolitan area (whether among the largest twelve), main Census region, and marital status, and create continuous variables for the worker's age and hourly wage. ${ }^{7}$ Most important, the QAL surveys also offer data on respondents' satisfaction with various nonwage characteristics of their jobs. While the sample elicits a large number of these subjective responses, I restrict the analyses to workers' feelings about: 1) How interesting is the job? 2) Does it offer opportunities to make friends? 3) Are the physical surroundings pleasant? 4) How good is the job security? 5) Can the worker develop his/her abilities? 6) Does the job use the worker's skills? and 7) Is there enough time to finish work? The responses are on a four-point scale. I treat those workers who stated that they were very or somewhat satisfied with the particular aspect of the job as being satisfied, and the others as being dissatisfied. These measures have the disadvantage that they are subjective, and thus liable to biases that arise because the workers' responses are partly affected directly by the wage they are paid (see Brown, 1980).

In order to examine whether amenities differ among natives depending on the importance of the immigrant population in the work force, I obtained from the 1990 Census for each MSA the fraction of the labor force, IMMPCT, that are immigrants. Merging this fraction with the May 1991 CPS Supplement for the timing study, and with the June 1991 CPS for the injury study, generates a very large sample of nonhispanic white native workers, and usefully large subsamples of native 
minorities, on which to test how work timing and injuries are affected by the presence of immigrants in the labor market. Because the data needed to construct IMMPCT are only available for metropolitan areas, however, all the analysis of this question is necessarily performed excluding the roughly one-third of workers who reside outside metropolitan areas.

\section{Do Natives and Immigrants Enjoy Different Amenities?}

\section{A. Work at Unpleasant Times}

In this Section I examine the first of the two questions dealing with the relation of immigration to native workers' on-the-job amenities, namely whether the packages of amenities received by natives differ from those received by otherwise identical immigrants. Consider first the objective information from the May 1991CPS Supplement on the disamenity, working in the evening or at night. In Table $1 \mathrm{I}$ list the means and their standard deviations of several economic and demographic measures and also the probability of work in the evenings or nights separately by sex and for native nonhispanic whites, blacks and Hispanics, and for immigrants. Immigrants constitute around 10 percent of the workers in this sample, perhaps very slightly above what other studies have indicated was the immigrant proportion of the labor force in the early 1990 s. $^{8}$ Immigrant men's weekly wages are below those of native whites, and their education is substantially below that of whites.

The first thing to note about the timing of work is that for all groups a not inconsiderable proportion of workers reports that the starting and ending times of their jobs bracket evening or night work. Nonetheless, these fractions are small compared to the nearly 90 percent of workers who are on the job at the peak work time, 3PM (Hamermesh, 1996a). There are no significant differences between immigrants and native nonhispanic white women in the probability of working evenings or nights. Male immigrants are, however, more likely than native nonhispanic whites to work evenings, 
Table 1. Means and Their Standard Errors, May 1991 CPS

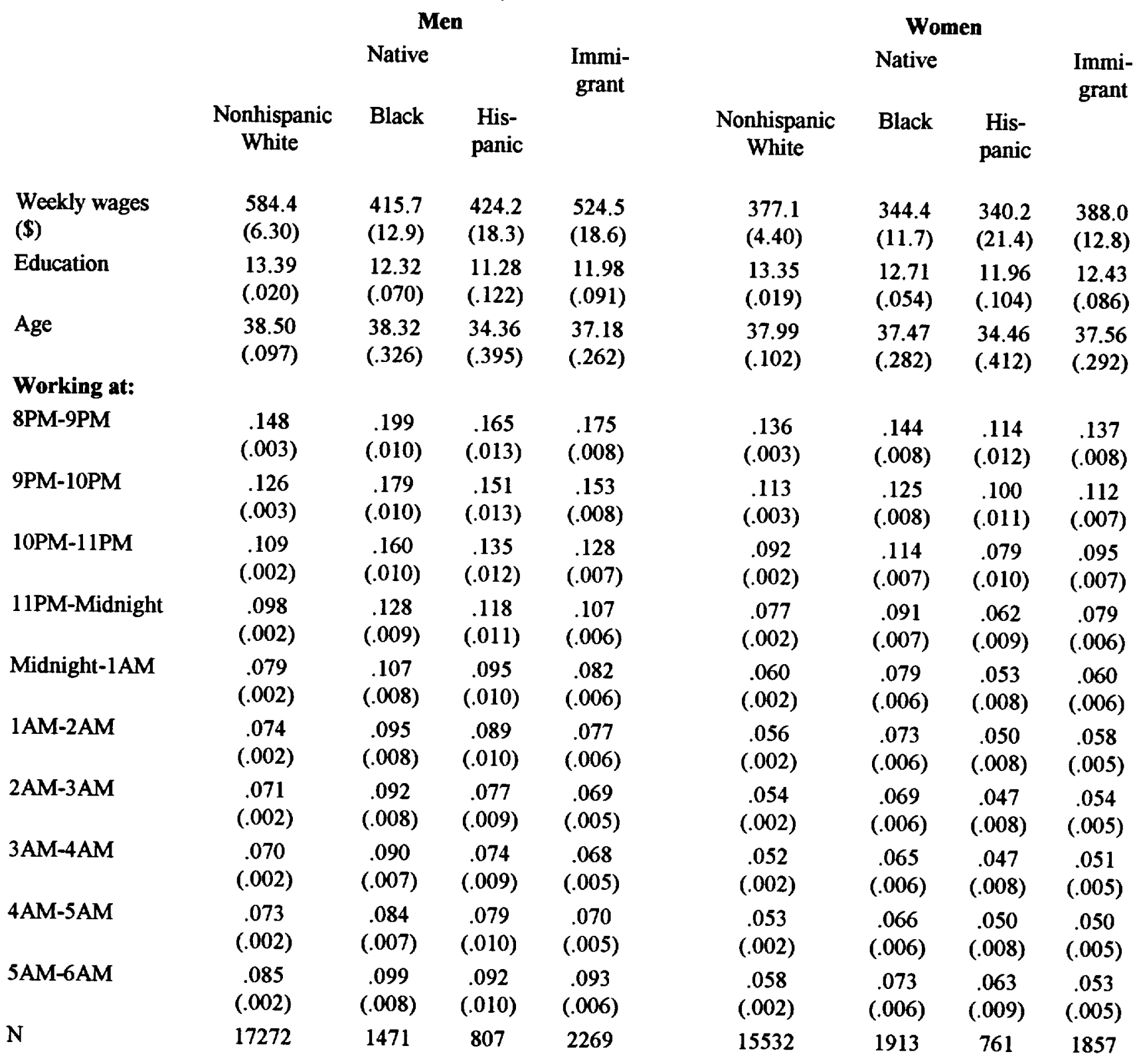


but their propensities to work nights are the same. The main intergroup difference in these data is that blacks, especially men, are significantly more likely than other workers to be at work at these times.

The same calculations as those underlying Table 1 were made with the samples broken down by educational attainment (high school graduation or more, and others). This decomposition of the sample allows us to examine whether segmentation by the taste for amenities might exist only among less-educated Americans and immigrants. The conclusion from Table 1 that there is little difference between immigrants and native nonhispanic whites, but that native blacks have substantially higher propensities to work evenings and nights, holds true for each education group.

Work timing is an especially crucial job disamenity, since the timing of work is inherent in one's choice of labor supply, which in turn depends on all the demographic and economic factors that have become standard in the literature. For that reason one cannot simply look at differences in means; instead, we need to adjust for as many observable differences among workers as is possible in order to infer whether workers with the same full income who differ by immigrant status enjoy different amounts of the particular amenity. The results of one such test are shown in Table 2 , which presents for each sex the adjusted excess probability of working at the particular time by immigrants, black natives and Hispanic natives compared to nonhispanic white natives. The derivatives from the probits in the top panel reflect adjustments for education, age, size of metropolitan area, marital status, presence of young children and region, all of which have been shown (Hamermesh, 1996b, Chapter 3) to have independent effects on the timing of work. The probits also hold constant for total daily workhours, since those people who work longer hours are perforce more likely to be at work at any particular hour of the day. 
Table 2. Effects of Immigrant Status and Ethnicity on the Timing of Work, May 1991 CPS*

\begin{tabular}{|c|c|c|c|c|c|c|c|c|c|}
\hline \multirow[b]{2}{*}{ Dependent Variable: } & \multicolumn{4}{|c|}{$\operatorname{Men}(N=22230)$} & & & \multicolumn{3}{|c|}{ Women $(N=20431)$} \\
\hline & $\begin{array}{l}\text { Mean } \\
\text { at Work }\end{array}$ & Immigrant & $\begin{array}{l}\text { Black } \\
\text { Native }\end{array}$ & $\begin{array}{c}\text { Hispanic } \\
\text { Native }\end{array}$ & & $\begin{array}{l}\text { Mean } \\
\text { at Work }\end{array}$ & Immigrant & $\begin{array}{l}\text { Black } \\
\text { Native }\end{array}$ & $\begin{array}{c}\text { Hispanic } \\
\text { Native }\end{array}$ \\
\hline Working at: & & & & & $\begin{array}{l}\text { Without } \\
\text { Industry }\end{array}$ & & & & \\
\hline 8PM-9PM & .155 & $\begin{array}{c}.029 \\
(.009)\end{array}$ & $\begin{array}{c}.057 \\
(.010)\end{array}$ & $\begin{array}{c}. .012 \\
(.010)\end{array}$ & & .136 & $\begin{array}{c}.011 \\
(.009)\end{array}$ & $\begin{array}{c}. .004 \\
(.007)\end{array}$ & $\begin{array}{c}. .033 \\
(.009)\end{array}$ \\
\hline 9PM-10PM & .134 & $\begin{array}{c}.024 \\
(.008)\end{array}$ & $\begin{array}{c}.058 \\
(.009)\end{array}$ & $\begin{array}{c}-.005 \\
(.009)\end{array}$ & & .114 & $\begin{array}{c}.003 \\
(.008)\end{array}$ & $\begin{array}{c}.003 \\
(.007)\end{array}$ & $\begin{array}{l}. .019 \\
(.008)\end{array}$ \\
\hline 10PM-11PM & .115 & $\begin{array}{c}.016 \\
(.008)\end{array}$ & $\begin{array}{c}.056 \\
(.008)\end{array}$ & $\begin{array}{l}-.004 \\
(.008)\end{array}$ & & .095 & $\begin{array}{c}.005 \\
(.007)\end{array}$ & $\begin{array}{c}.015 \\
(.006)\end{array}$ & $\begin{array}{c}-.010 \\
(.008)\end{array}$ \\
\hline 11PM-Midnight. & .102 & $\begin{array}{c}.008 \\
(.007)\end{array}$ & $\begin{array}{c}.035 \\
(.008)\end{array}$ & $\begin{array}{c}-.003 \\
(.008)\end{array}$ & & .079 & $\begin{array}{c}.003 \\
(.006)\end{array}$ & $\begin{array}{c}.010 \\
(.005)\end{array}$ & $\begin{array}{l}-.013 \\
(.006)\end{array}$ \\
\hline Midnight-1AM & .083 & $\begin{array}{c}.005 \\
(.006)\end{array}$ & $\begin{array}{c}.035 \\
(.007)\end{array}$ & $\begin{array}{c}.000 \\
(.007)\end{array}$ & & .062 & $\begin{array}{l}. .001 \\
(.004)\end{array}$ & $\begin{array}{c}.016 \\
(.004)\end{array}$ & $\begin{array}{c}-.006 \\
(.005)\end{array}$ \\
\hline 1AM-2AM & .077 & $\begin{array}{c}.005 \\
(.006)\end{array}$ & $\begin{array}{c}.029 \\
(.006)\end{array}$ & $\begin{array}{l}.000 \\
(.006)\end{array}$ & & .058 & $\begin{array}{l}.001 \\
(.004)\end{array}$ & $\begin{array}{c}.017 \\
(.004)\end{array}$ & $\begin{array}{c}-.005 \\
(.005)\end{array}$ \\
\hline 2AM-3AM & .073 & $\begin{array}{c}.004 \\
(.006)\end{array}$ & $\begin{array}{c}.029 \\
(.006)\end{array}$ & $\begin{array}{c}-.003 \\
(.006)\end{array}$ & & .055 & $\begin{array}{l}-.001 \\
(.004)\end{array}$ & $\begin{array}{c}.016 \\
(.004)\end{array}$ & $\begin{array}{c}-.003 \\
(.004)\end{array}$ \\
\hline $3 \mathrm{AM}-4 \mathrm{AM}$ & .072 & $\begin{array}{c}.003 \\
(.005)\end{array}$ & $\begin{array}{c}.027 \\
(.006)\end{array}$ & $\begin{array}{c}-.004 \\
(.006)\end{array}$ & & .054 & $\begin{array}{l}. .003 \\
(.004)\end{array}$ & $\begin{array}{c}.014 \\
(.004)\end{array}$ & $\begin{array}{l}-.000 \\
(.004)\end{array}$ \\
\hline 4AM-5AM & .074 & $\begin{array}{c}.002 \\
(.006)\end{array}$ & $\begin{array}{c}.018 \\
(.006)\end{array}$ & $\begin{array}{l}-.001 \\
(.006)\end{array}$ & & .054 & $\begin{array}{c}-.004 \\
(.004)\end{array}$ & $\begin{array}{c}.015 \\
(.004)\end{array}$ & $\begin{array}{c}.001 \\
(.005)\end{array}$ \\
\hline $5 \mathrm{AM}-6 \mathrm{AM}$ & .088 & $\begin{array}{l}.008 \\
(.006)\end{array}$ & $\begin{array}{c}.019 \\
(.007)\end{array}$ & $\begin{array}{l}-.003 \\
(.007)\end{array}$ & & .060 & $\begin{array}{c}. .004 \\
(.004)\end{array}$ & $\begin{array}{c}.016 \\
(.004)\end{array}$ & $\begin{array}{c}. .001 \\
(.005)\end{array}$ \\
\hline & & & & & $\begin{array}{l}\text { With } \\
\text { Industry }\end{array}$ & & & & \\
\hline 8PM-9PM & & $\begin{array}{c}.012 \\
(.008)\end{array}$ & $\begin{array}{c}.039 \\
(.009)\end{array}$ & $\begin{array}{c}-.014 \\
(.010)\end{array}$ & & & $\begin{array}{c}.001 \\
(.008)\end{array}$ & $\begin{array}{c}-.005 \\
(.008)\end{array}$ & $\begin{array}{c}-.028 \\
(.010)\end{array}$ \\
\hline 9PM-10PM & & $\begin{array}{c}.010 \\
(.008)\end{array}$ & $\begin{array}{c}.039 \\
(.008)\end{array}$ & $\begin{array}{c}-.003 \\
(.009)\end{array}$ & & & $\begin{array}{l}. .005 \\
(.007)\end{array}$ & $\begin{array}{c}-.002 \\
(.007)\end{array}$ & $\begin{array}{l}-.015 \\
(.009)\end{array}$ \\
\hline 10PM-11PM & & $\begin{array}{c}.007 \\
(.007)\end{array}$ & $\begin{array}{c}.037 \\
(.008)\end{array}$ & $\begin{array}{c}-.004 \\
(.008)\end{array}$ & & & $\begin{array}{c}-.001 \\
(.007)\end{array}$ & $\begin{array}{c}.007 \\
(.006)\end{array}$ & $\begin{array}{c}-.009 \\
(.008)\end{array}$ \\
\hline 11PM-Midnight & & $\begin{array}{c}.002 \\
(.007)\end{array}$ & $\begin{array}{c}.021 \\
(.007)\end{array}$ & $\begin{array}{l}-.001 \\
(.008)\end{array}$ & & & $\begin{array}{c}-.001 \\
(.006)\end{array}$ & $\begin{array}{c}.003 \\
(.006)\end{array}$ & $\begin{array}{l}-.014 \\
(.007)\end{array}$ \\
\hline Midnight-1AM & & $\begin{array}{l}.003 \\
(.006)\end{array}$ & $\begin{array}{c}.021 \\
(.006)\end{array}$ & $\begin{array}{c}-.000 \\
(.007)\end{array}$ & & & $\begin{array}{c}-.002 \\
(.005)\end{array}$ & $\begin{array}{c}.010 \\
(.005)\end{array}$ & $\begin{array}{l}-.007 \\
(.006)\end{array}$ \\
\hline 1AM-2AM & & $\begin{array}{l}.005 \\
(.006)\end{array}$ & $\begin{array}{c}.016 \\
(.006)\end{array}$ & $\begin{array}{l}-.001 \\
(.007)\end{array}$ & & & $\begin{array}{l}-.000 \\
(.005)\end{array}$ & $\begin{array}{c}.010 \\
(.005)\end{array}$ & $\begin{array}{c}-.006 \\
(.006)\end{array}$ \\
\hline 2AM-3AM & & $\begin{array}{c}.005 \\
(.006)\end{array}$ & $\begin{array}{c}.017 \\
(.006)\end{array}$ & $\begin{array}{c}-.003 \\
(.007)\end{array}$ & & & $\begin{array}{c}-.002 \\
(.005)\end{array}$ & $\begin{array}{c}.009 \\
(.005)\end{array}$ & $\begin{array}{c}-.003 \\
(.006)\end{array}$ \\
\hline 3AM-4AM & & $\begin{array}{c}.005 \\
(.006)\end{array}$ & $\begin{array}{c}.016 \\
(.006)\end{array}$ & $\begin{array}{c}-.004 \\
(.007)\end{array}$ & & & $\begin{array}{c}-.005 \\
(.005)\end{array}$ & $\begin{array}{c}.007 \\
(.004)\end{array}$ & $\begin{array}{c}-.001 \\
(.006)\end{array}$ \\
\hline $4 \mathrm{AM}-5 \mathrm{AM}$ & & $\begin{array}{c}.005 \\
(.006)\end{array}$ & $\begin{array}{c}.008 \\
(.006)\end{array}$ & $\begin{array}{c}-.000 \\
(.007)\end{array}$ & & & $\begin{array}{l}. .007 \\
(.005)\end{array}$ & $\begin{array}{c}.008 \\
(.005)\end{array}$ & $\begin{array}{c}.000 \\
(.006)\end{array}$ \\
\hline $5 A M-6 A M$ & & $\begin{array}{c}.011 \\
(.006)\end{array}$ & $\begin{array}{c}.005 \\
(.007)\end{array}$ & $\begin{array}{c}-.001 \\
(.007)\end{array}$ & & & $\begin{array}{c}-.008 \\
(.005)\end{array}$ & $\begin{array}{c}.009 \\
(.005)\end{array}$ & $\begin{array}{c}.002 \\
(.006)\end{array}$ \\
\hline
\end{tabular}

- Other variables included in the probits in the upper panel are years of schooling, a quadratic in age, a vector of variables for the size of the metropolitan area, marital status, presence of children under age 6 , residence in the "Rust Belt," and total hours worked. The same variables are included in the fixed-effects least-squares regressions reported in the bottom part of the panel. 
Immigrant men are significantly more likely than demographically identical native nonhispanic whites to be at work in the evenings, but their propensity for night work is no different. Immigrant women are no more likely than native nonhispanic whites to be at work after 7PM and before 6AM. African-American workers of both sexes, on the other hand, are significantly more likely than native nonhispanic whites to be at work at most of these unusual times, and also significantly more likely than immigrants or native Hispanics to be at work at these times. Among men this is especially true for evening work, while among women the effect is strongest for night work (which is much less frequent than evening work). Among Hispanic natives the propensity to work at these times differs little from that of native nonhispanic whites; if anything, they are less likely than nonhispanic white natives to accept this particular disamenity. Comparing the relative impacts of race and immigrant status, it is clear that otherwise identical black men are significantly more likely than immigrant or other men to be at work in the evening or at night, while black women are more likely than immigrant or other women to be at work at night. ${ }^{9}$

The estimates in the top panel ignore interindustry differences in workplace amenities. I believe those estimates are the appropriate ones to use in comparing the amenities enjoyed by different groups, since interindustry differences that are correlated with race or immigrant status may reflect exactly the intergroup differences in preferences, and thus location on the risk-rewards locus, that we are trying to isolate. These estimates indicate differences among groups in workers' wellbeing rather than merely their possibly voluntary matching to particular technologies. Nonetheless, to examine whether these intergroup differences merely reflect differences in industrial affiliation by ethnicity or national origin, I estimate linear probability models for work at each hour that include the 
same variables as the probits, but that also add large vectors of indicator variables (over 200) that represent presence in each three- or four-digit SIC industry.

The results from the top panel of Table 2 become somewhat attenuated in the results presented in the bottom panel, especially for immigrant men, for whom the difference in evening work compared to native white men is no longer significant. Among native black men, however, we still find a significantly greater propensity to work evenings and most night hours than among nonhispanic white natives, and among native black women the propensity to work nights exceeds that of nonhispanic white natives. Moreover, native black men are more likely than immigrants (in a few cases significantly so) to work in the evening and most night hours, while black women are significantly more likely that immigrant women to work nights.

Nearly three-fourths of the immigrants in the June 1991 CPS arrived in the United States after 1969. Since much of the attention of specialists in immigration has been devoted to demonstrating how the behavior of these more recent immigrant groups has differed from that of their earlier counterparts (e.g., Borjas, 1995), it is worth examining whether their tastes for work are implicitly such as to lead them to obtain a different, and presumably inferior set of workplace disamenities. Accordingly, I reestimated the probits underlying Table 2 by replacing the immigration indicator with separate indicators for whether the immigrant arrived before 1970 or after 1969 . Among women the results look very much like those in the Table: Neither early nor recent immigrants differ from native nonhispanic whites in their adjusted propensities to work hours between 8PM and 6AM. The same is true for immigrant men working after midnight. Before midnight, however, while recent immigrants' propensities to work differ little from those of native whites, immigrants who arrived before 1970 are significantly more likely than native whites to be at work. This is the only piece of 
evidence I find in this study of any group of immigrants experiencing objectively inferior amenities to those enjoyed by native nonhispanic whites. That it occurs among earlier immigrants to the U.S. seems to run counter to the notions of immigrant isolation that underlay the model of Section II.

Yet another possibility is that it is not immigrant status per se that matters, but rather the immigrant's country of origin. Perhaps those who emigrated from countries where workers experience workplace amenities similar to those in the U.S. do compete with observationally identical natives, but that immigrants from less developed countries are willing to take jobs with disamenities that natives will not accept. To examine this I divided the sample into immigrants from Canada, Oceania and Europe versus others and included two separate indicator variables instead of one. The results for men differed little from those in the table. Among women, at a few of the work times immigrants from non-European, non-English speaking countries had inferior work times, but most of the differences were quite small and insignificant statistically.

The results in Table 2 are not adjusted for workers' wages. Essentially they fail to account for the unobservables that contribute to determining both wages and disamenities. The reason for this failure is that information on earnings by immigrant status is only available for the one-fourth of the sample who were in the outgoing rotation groups of the June 1991 CPS. Reestimating the probits on this much smaller set of data, and including all the variables in Table 2 plus weekly earnings, does not alter the conclusions that the timing of work by immigrants differs little from that of native whites, and is somewhat more favorable than that of otherwise identical native blacks. ${ }^{10}$

\section{B. Risk of Injury}

The June 1991 CPS merged with industry aggregate risks of occupational injury/illness provides the opportunity to examine yet another nonpecuniary aspect of the job. Ideally we would 
like to obtain matched worker-firm data that shows the risk of injury on the job at the worker's firm. (That would be analogous to the information used in Part A above.) Failing that, we fall back on information on the incidence per 100 employees and the duration in days of injuries that result in lost workdays from the set of mainly three-digit industries matched to the June 1991 CPS data.

The means and standard errors of these two measures of injury risk in the workplace are presented by sex for each of the four demographic groups in Table 3. The results are striking: Among native nonhispanic white, native Hispanic and immigrant females there are no significant differences in the incidence or duration of workplace injuries. Black females, however, are somewhat more likely to be in a (narrowly-defined) industry where the risk of workplace injury is higher. Among males there are no significant differences between native whites and Hispanics in the incidence or duration of injuries; but immigrants are much more likely to be in industries where the incidence and duration of workplace injuries are low. African-Americans, on the other hand, are more likely than other groups to be in industries where the incidence of workplace injuries is high. That the duration of workplace injuries in industries that disproportionately employ immigrant workers is lower than elsewhere suggests that the burden on immigrants of this particular disamenity is even less severe than one might infer at first glance, since it is lengthened duration rather than a greater incidence of injury that workers implicitly view as the more severe disamenity (Hamermesh and Wolfe, 1990). ${ }^{11}$

Given the evidence in Table 1 on the education and age of immigrants compared to natives, adjusting the injury rates and duration for demographic differences is likely to increase our estimates of the relative advantage of immigrants over native whites. It might, however, reduce the apparent differences between African-Americans and others in the incidence of job-related injuries. Table 4 
Table 3. Means and Standard Errors, June 1991 CPS

\begin{tabular}{|c|c|c|c|c|c|c|c|c|}
\hline & \multicolumn{4}{|c|}{ Men } & \multicolumn{4}{|c|}{ Women } \\
\hline & \multirow[b]{2}{*}{$\begin{array}{l}\text { Nonhispanic } \\
\text { White }\end{array}$} & \multicolumn{2}{|l|}{ Native } & \multirow{2}{*}{$\begin{array}{c}\text { Immi- } \\
\text { grant }\end{array}$} & \multicolumn{3}{|c|}{ Native } & \multirow{2}{*}{$\begin{array}{l}\text { Immi- } \\
\text { grant }\end{array}$} \\
\hline & & Black & $\begin{array}{l}\text { His- } \\
\text { panic }\end{array}$ & & $\begin{array}{l}\text { Nonhispanic } \\
\text { White }\end{array}$ & Black & $\begin{array}{l}\text { His- } \\
\text { panic }\end{array}$ & \\
\hline $\begin{array}{c}\text { Injury Rate/100 } \\
\text { Employees }\end{array}$ & $\begin{array}{r}4.55 \\
(2.70)\end{array}$ & $\begin{array}{c}4.88 \\
(2.87)\end{array}$ & $\begin{array}{r}4.64 \\
(2.59)\end{array}$ & $\begin{array}{c}4.35 \\
(2.52)\end{array}$ & $\begin{array}{c}3.35 \\
(2.29)\end{array}$ & $\begin{array}{c}3.78 \\
(2.53)\end{array}$ & $\begin{array}{c}3.43 \\
(2.31)\end{array}$ & $\begin{array}{r}3.49 \\
(2.31)\end{array}$ \\
\hline $\begin{array}{l}\text { Injury Duration } \\
\text { in Days }\end{array}$ & $\begin{array}{l}19.20 \\
(3.52)\end{array}$ & $\begin{array}{l}19.22 \\
(3.45)\end{array}$ & $\begin{array}{l}19.31 \\
(3.58)\end{array}$ & $\begin{array}{l}18.68 \\
(2.95)\end{array}$ & $\begin{array}{l}18.12 \\
(2.87)\end{array}$ & $\begin{array}{l}18.05 \\
(2.52)\end{array}$ & $\begin{array}{l}18.10 \\
(2.79)\end{array}$ & $\begin{array}{l}18.26 \\
(2.58)\end{array}$ \\
\hline $\mathrm{N}$ & 22312 & 2062 & 904 & 2628 & 19965 & 2529 & 850 & 1853 \\
\hline
\end{tabular}


presents regression estimates designed to adjust for these demographic differences. The variables included as controls in the top panel here are identical to those included in the top panel of Table 2, except that I have excluded total workhours. Adjusting for demographic differences does not change the conclusions based on the means shown in Table 3: The duration and incidence of injuries among immigrant men are lower, although not significantly so, than among native men. Even after adjustment for demographics native black men and women are still in industries with higher risks of injury.

The difficulty with these estimates is that, unlike the estimates in Part A, the disamenities reflect solely the worker's industry, not anything unique to the worker. Because the injury data are industry-specific, we cannot hold constant for the industry the worker is located in. We can, however, adjust for the narrow occupation of each worker, and thus ask whether within particular occupations and after adjustment for demographic differences, immigrants or African-Americans are in industries where injury risks differ from those of native nonhispanic whites. The results of estimates in which indicator variables for over 450 occupations are included are presented in the bottom panel of Table 4. Even after this adjustment immigrant men are less subject to the risk of workplace injury than other groups; and with these further adjustments the same is true for immigrant women. None of these differences is significant, but they still are in the same direction as before this very extensive adjustment was made.

In Part A I demonstrated a substantial difference in some cases between the disamenities experienced by recent immigrants and those of earlier immigrants. Such differences are not apparent in the distribution of the risks of workplace injuries. If we aggregate dates of immigration using the same indicator of pre- or post-1970 arrival, we find roughly the same negative cofficients for both 
Table 4. Effects of Immigrant Status and Ethnicity on Injury Rates and Duration, June 1991 CPS*

$$
\text { Men }(\mathrm{N}=27918)
$$

$\begin{array}{lllc} & \text { Immigrant } & \text { Black } & \text { Hispanic } \\ \text { Dependent Variable: } & & \text { Native } & \text { Native }\end{array}$

$\begin{array}{ccc}-.264 & .115 & -.129 \\ (.158) & (.175) & (.103) \\ -.630 & .006 & -.128 \\ (.280) & (.195) & (.168)\end{array}$

Injury Rate/100

Employees

Injury Duration in

Days

$\begin{array}{ccc}-.072 & .062 & -.041 \\ (.134) & (.147) & (.088) \\ -.195 & -.010 & .022 \\ (.238) & (.167) & (.142)\end{array}$

Women (N = 25209)

Immigrant Black His-

Native panic

Native

Without

Occupation

$\begin{array}{ccc}.144 & .360 & -.082 \\ (.112) & (.192) & (.132) \\ .043 & -.129 & -.170 \\ (.156) & (.162) & (.195)\end{array}$

With

Occupation

$\begin{array}{lll}-.092 & .092 & -.024 \\ (.097) & (.164) & (.112) \\ -.022 & -.160 & -.032 \\ (.143) & (.148) & (.176)\end{array}$

- Other variables included in the regressions in the upper panel are years of schooling, a quadratic in age, a vector of variables for the size of the metropolitan area, marital status, presence of children under age 6 , and residence in the "Rust Belt." The same variables are included in the occupation fixed-effects least-squares regressions reported in the bottom part of the panel. The standard errors of the coefficient estimates are robust to clustering of observations within three- and four-digit industries. 
groups, and for both injury rates and duration. Not only are immigrants located in industries where the risk of injury is somewhat lower than that of native whites; that is equally true for recent and for earlier immigrants.

\section{Subjective Satisfaction with Job Characteristics}

Clearly the most useful analyses are of the actual distribution of amenities experienced by immigrants, African-Americans and others. Nonetheless, it is worth examining their subjective responses to the disamenities they face, in part merely to obtain more information on the phenomena, in part because the subjective information covers a wider range of disamenities. Table 5 presents the means and their standard deviations for these and the demographic variables separately for white and black natives, and for immigrants ages 16-69 inclusive. Remembering that the QAL data are from the 1970s, it is not surprising that the immigrants are actually slightly older on average than natives. So too, it is unsurprising that they are also slightly better educated than natives. Interestingly, and also quite consistent with results using other samples, the QAL immigrants' hourly wages are below those of white natives despite their higher educational attainment (obtained no doubt at least in part in foreign educational institutions). Blacks' wages are 73 and 81 percent of those of white natives of the same sex, roughly comparable to what is shown in more comprehensive surveys (e.g., March CPS data) for these periods and these age groups.

The bottom part of Table 5 presents the means of workers' satisfaction along each of the seven criteria we use to reflect subjective views of workplace amenities. Only three significant differences exist between immigrants and either white or black native workers in the QAL: 1) Immigrants are distinctly less likely than natives of either race to respond that their jobs offer them the chance to make friends; 2) They are significantly more likely than natives of either race to state 
Table 5. Means and Their Standard Errors, Pooled QAL 1971,1978

White Natives Black Natives Immigrants

$\begin{array}{lccc}\text { Hourly Wage (\$) } & 5.30 & 3.85 & 5.22 \\ \text { Years of Schooling: } & (.153) & (.177) & (.351) \\ \leq 12 & & & \\ & .563 & .701 & .494 \\ 13-15 & (.009) & (.025) & (.040) \\ & .246 & .184 & .212 \\ 16+ & (.008) & (.021) & (.032) \\ & .186 & .109 & .262 \\ \text { Age } & (.007) & (.017) & (.035) \\ & 38.46 & 38.98 & 39.24 \\ \text { Interesting Job } & (.258) & (.695) & (.941) \\ & .911 & .886 & .887 \\ \text { Chance to Make Friends } & (.005) & (.017) & (.025) \\ & .895 & .870 & .792 \\ \text { Nice Surroundings } & (.006) & (.018) & (.032) \\ & .824 & .830 & .8815 \\ \text { Job Security } & (.007) & (.020) & (.026) \\ & .840 & .796 & .849 \\ \text { Can Develop Skills } & (.007) & (.022) & (.028) \\ & .785 & .731 & .719 \\ \text { Can Use skills } & (.008) & (.024) & (.036) \\ & .800 & .752 & .761 \\ \text { Enough Time to Do } & (.008) & (.023) & (.034) \\ \text { Work } & .820 & .847 & .856 \\ & (.007) & (.019) & (.028) \\ \text { N }= & & & 160 \\ & 2798 & 348 & \end{array}$


Table 6. Effects of Immigrant Status and Race on Job Characteristics, Pooled 1971, 1978 QAL, (N = 2810)"

\begin{tabular}{|c|c|c|c|c|}
\hline & \multicolumn{2}{|c|}{ Foreign-born } & \multicolumn{2}{|c|}{$\begin{array}{l}\text { Foreign-born or both parents } \\
\text { foreign-born }\end{array}$} \\
\hline & Immigrant & Black & Immigrant & Black \\
\hline \multicolumn{5}{|l|}{ Dependent Variable: } \\
\hline Interesting Job & $\begin{array}{l}-.040 \\
(.026)\end{array}$ & $\begin{array}{c}-.026 \\
(.018)\end{array}$ & $\begin{array}{l}-.023 \\
(.021)\end{array}$ & $\begin{array}{l}-.026 \\
(.018)\end{array}$ \\
\hline Chance to Make Friends & $\begin{array}{l}-.060 \\
(.029)\end{array}$ & $\begin{array}{c}-.022 \\
(.021)\end{array}$ & $\begin{array}{l}-.029 \\
(.023)\end{array}$ & $\begin{array}{l}-.022 \\
(.021)\end{array}$ \\
\hline Nice Surroundings & $\begin{array}{c}.044 \\
(.035)\end{array}$ & $\begin{array}{c}.019 \\
(.025)\end{array}$ & $\begin{array}{l}.040 \\
(.028)\end{array}$ & $\begin{array}{l}.020 \\
(.025)\end{array}$ \\
\hline Job Security & $\begin{array}{l}.029 \\
(.031)\end{array}$ & $\begin{array}{l}-.036 \\
(.025)\end{array}$ & $\begin{array}{l}.039 \\
(.025)\end{array}$ & $\begin{array}{l}-.034 \\
(.025)\end{array}$ \\
\hline Can Develop Skills & $\begin{array}{l}-.075 \\
(.039)\end{array}$ & $\begin{array}{l}-.050 \\
(.028)\end{array}$ & $\begin{array}{l}-.025 \\
(.031)\end{array}$ & $\begin{array}{l}-.049 \\
(.028)\end{array}$ \\
\hline Can Use Skills & $\begin{array}{l}-.084 \\
(.038)\end{array}$ & $\begin{array}{l}-.078 \\
(.027)\end{array}$ & $\begin{array}{l}-.066 \\
(.031)\end{array}$ & $\begin{array}{l}-.080 \\
(.027)\end{array}$ \\
\hline Enough Time to Do Work & $\begin{array}{l}.035 \\
(.034)\end{array}$ & $\begin{array}{l}.026 \\
(.025)\end{array}$ & $\begin{array}{l}.053 \\
(.027)\end{array}$ & $\begin{array}{l}.028 \\
(.025)\end{array}$ \\
\hline
\end{tabular}

- Other variables included in the probits are indicators for sex, a quadratic in age, the hourly wage rate, vectors of indicators representing the size of the metropolitan area, the main Census regions, and educational attainment, marital status, and a separate intercept for 1971. 
that their workplace surroundings are more pleasant; and 3) They are significantly less likely than white natives to state that their job provides them with opportunities for development. While these differences are significant, the lack of other significant differences, and the implication from these that immigrants view at least some of these amenities as distinctly better than do natives, hints that these data too provide little evidence that immigrants experience inferior workplace amenities.

A formal test for intergroup differences in amenities requires that we hold constant for the demographic characteristics that might reflect tastes for amenities and for differences in workers' earnings that might indicate differences in their full incomes that allow them to "purchase" better working conditions. ${ }^{12}$ The results of estimating probits on the seven job characteristics are reflected in the estimated derivatives with respect to immigrant status and race, and their standard errors, that are presented in Table 6 . The left-hand panel defines immigrant status in the conventional manner; the right-hand panel defines it more broadly to include as immigrants also those workers whose parents were both born outside the United States.

Some of the differences in the means that we observed in Table 5 remain, in particular, the fact that immigrants view their jobs as offering fewer chances to develop their skills and fewer chances to make friends than do white natives. While immigrants view their surroundings as more appealing than do otherwise identical white natives, the difference is insignificant. They do, however, claim that they are less able to use their skills than do white natives. Thus along three of the seven nonwage dimensions of work immigrants are significantly less satisfied with nonwage aspects of their jobs than are native whites with identical demographic characteristics who earn the same hourly wage. Blacks respond very similarly to immigrants: The effect of race on the responses is the same sign as that of immigrant status along six out of the seven dimensions, although never so large. This 
finding suggests that, surely for different reasons, subjective views of workplace amenities by immigrants and blacks may be somewhat different from those enjoyed by similarly endowed white natives. What is particularly interesting, however, is that the results for immigrants change when we include first-generation Americans in the immigrant category. All of the derivatives in column (3) of Table 2 are attenuated from their values in column (1), where only workers who are themselves immigrants were included in the definition of the indicator variable. Taken together the results suggest that, while immigrants may enjoy slightly less desirable amenities than white natives on jobs paying identical wages, even those small differences are reduced after one generation and roughly equal the differences between blacks and native whites. ${ }^{13}$

This finding of some significant differences between native blacks and native whites, and between immigrants and native whites, does not necessarily imply the existence of workplace discrimination. Rather, given that we held hourly wages constant, it might mean that workers in these groups, whose family incomes are more uncertain than those of native whites, choose to spend their full earnings on jobs that are tilted toward offering more money income and fewer amenities. The differences are not great. At most they offer only a tiny bit of very tentative (because we are examining workers' subjective responses) evidence that immigrants do take jobs with different amenities from those of native whites, and thus that there may be noncompetition between immigrants and native whites. The results also imply, however, that those jobs are quite close or even superior in the quality of the amenities that they offer to the ones that otherwise identical native black workers are more likely to take. 


\section{A Synthesis}

Immigrants and native nonhispanic whites may have different job-related activities: There are, after all, many dimensions of work along which job characteristics might differ that we have not examined. A fair conclusion from all the investigations here, however, is that there are few important differences between immigrants and native nonhispanic whites in work timing, the rate or duration of work-related injuries, or in satisfaction with most job-related characteristics once we account for differences in their demographics and their earnings. This conclusion implies that there is a strong basis for believing that immigrants and native whites will be competing directly at least to some extent in the labor market.

Even along those dimensions where immigrants do experience fewer amenities than native whites, their outcomes are similar to or perhaps more attractive than those of native blacks. That suggests that, to the extent that the differences in the willingness to accept disamenities might generate noncompetition in the labor market, immigrants and native whites seem quite similar and should be viewed as potentially competing groups. Indeed, the evidence here implies that, if any group of workers is willing to accept jobs that otherwise identical workers will not accept, it is native blacks. Viewed differently, labor-market discrimination is apparent against African-Americans in the nonwage aspects of their jobs even after adjustment for the wages they are paid.

\section{Do Immigrants Affect Natives' Workplace Amenities?}

If immigrants and natives differ little in the amenities they enjoy on jobs measured at a fixed wage and among workers who are demographically otherwise identical, we should not expect to see any effect of an influx of immigrants on the amenities enjoyed by natives. Nonetheless, to examine this possibility I analyze how the 1990 Census information on IMMPCT linked to the May and June 
1991 CPS data is related to the timing of work and the incidence and duration of workplace injuries among natives resident in metropolitan areas. Initial insight into the main question of this Section can be obtained by examining how these outcomes are related to differences in the importance of immigrants in the labor market. Table 7 shows the means of these outcomes for all natives, and for nonhispanic whites, blacks and Hispanics, separately for men and women. The upper figure in each pair is the mean in those metropolitan areas where more than 10 percent of the work force are immigrants; the lower figure (in parentheses) is the mean in areas where 10 percent or less of the labor force consists of immigrants.

The results on the timing of work are striking and completely surprising: At each evening and night hour, and for each subgroup of natives except black women working at night, the probability of working is lower in the areas where immigrants exceed 10 percent of the population. Implicitly immigration appears to be raising the amenities enjoyed by native workers. In terms of our model, that would imply that the identity of the marginal firm is changing, which is inconsistent with the implications of the previous section. Given the standard deviations of these means that were shown in Table 1, most of these differences are significant. Just the opposite is true for injury characteristics: Among both men and women injury rates and durations are somewhat, although not statistically significantly higher in areas where immigrants constitute more than 10 percent of the population.

Do the remarkable differences in the timing of work between natives distinguished by the native-immigrant composition of their area disappear once we account for demographic and economic differences among the ethnic groups? The top half of Table 8 lists the derivatives and their standard errors calculated from probits relating the probability of working evening and night hours to the fraction of immigrants in the metropolitan area and to the same set of controls used in Table 2. 
Table 7. Natives' Probability of Working and Injury Outcomes, in High (Low) Percentage Immigrant MSAs, May, June 1991 CPS *

\begin{tabular}{|c|c|c|c|c|c|c|c|c|}
\hline & \multicolumn{4}{|c|}{ Men } & \multicolumn{4}{|c|}{ Women } \\
\hline & All & $\begin{array}{l}\text { Nonhispanic } \\
\text { White }\end{array}$ & Black & Hispanic & All & $\begin{array}{l}\text { Nonhispanic } \\
\text { White }\end{array}$ & Black & Hispanic \\
\hline \multicolumn{9}{|l|}{ Working at: } \\
\hline 8PM-9PM & $\begin{array}{c}.135 \\
(.159)\end{array}$ & $\begin{array}{l}.126 \\
(.152)\end{array}$ & $\begin{array}{l}.168 \\
(.221)\end{array}$ & $\begin{array}{l}.156 \\
(.219)\end{array}$ & $\begin{array}{l}.116 \\
(.141)\end{array}$ & $\begin{array}{l}.120 \\
(.137)\end{array}$ & $\begin{array}{l}.120 \\
(.157)\end{array}$ & $\begin{array}{c}.074 \\
(.189)\end{array}$ \\
\hline 9PM-10PM & $\begin{array}{l}.115 \\
(.139)\end{array}$ & $\begin{array}{l}.104 \\
(.132)\end{array}$ & $\begin{array}{l}.166 \\
(.198)\end{array}$ & $\begin{array}{l}.147 \\
(.200)\end{array}$ & $\begin{array}{c}.099 \\
(.116)\end{array}$ & $\begin{array}{l}.100 \\
(.112)\end{array}$ & $\begin{array}{l}.106 \\
(.132)\end{array}$ & $\begin{array}{c}.070 \\
(.152)\end{array}$ \\
\hline 10PM-11PM & $\begin{array}{c}.099 \\
(.121)\end{array}$ & $\begin{array}{l}.089 \\
(.114)\end{array}$ & $\begin{array}{l}.155 \\
(.174)\end{array}$ & $\begin{array}{l}.127 \\
(.181)\end{array}$ & $\begin{array}{c}.083 \\
(.096)\end{array}$ & $\begin{array}{c}.082 \\
(.091)\end{array}$ & $\begin{array}{l}.100 \\
(.127)\end{array}$ & $\begin{array}{l}.057 \\
(.116)\end{array}$ \\
\hline 11PM-Midnight & $\begin{array}{l}.085 \\
(.108)\end{array}$ & $\begin{array}{c}.076 \\
(.103)\end{array}$ & $\begin{array}{l}.125 \\
(.145)\end{array}$ & $\begin{array}{l}.111 \\
(.156)\end{array}$ & $\begin{array}{c}.068 \\
(.079)\end{array}$ & $\begin{array}{c}.065 \\
(.076)\end{array}$ & $\begin{array}{c}.091 \\
(.095)\end{array}$ & $\begin{array}{c}.046 \\
(.098)\end{array}$ \\
\hline Midnight-1AM & $\begin{array}{c}.068 \\
(.086)\end{array}$ & $\begin{array}{c}.058 \\
(.082)\end{array}$ & $\begin{array}{l}.116 \\
(.110)\end{array}$ & $\begin{array}{c}.087 \\
(.125)\end{array}$ & $\begin{array}{c}.053 \\
(.062)\end{array}$ & $\begin{array}{c}.047 \\
(.060)\end{array}$ & $\begin{array}{c}.080 \\
(.076)\end{array}$ & $\begin{array}{c}.046 \\
(.073)\end{array}$ \\
\hline $1 \mathrm{AM}-2 \mathrm{AM}$ & $\begin{array}{c}.062 \\
(.080)\end{array}$ & $\begin{array}{c}.054 \\
(.076)\end{array}$ & $\begin{array}{l}.100 \\
(.103)\end{array}$ & $\begin{array}{l}.081 \\
(.119)\end{array}$ & $\begin{array}{l}.049 \\
(.058)\end{array}$ & $\begin{array}{c}.043 \\
(.057)\end{array}$ & $\begin{array}{c}.075 \\
(.069)\end{array}$ & $\begin{array}{l}.044 \\
(.067)\end{array}$ \\
\hline 2AM-3AM & $\begin{array}{c}.059 \\
(.076)\end{array}$ & $\begin{array}{l}.051 \\
(.072)\end{array}$ & $\begin{array}{l}.100 \\
(.100)\end{array}$ & $\begin{array}{c}.067 \\
(.119)\end{array}$ & $\begin{array}{l}.047 \\
(.055)\end{array}$ & $\begin{array}{c}.042 \\
(.054)\end{array}$ & $\begin{array}{l}.071 \\
(.067)\end{array}$ & $\begin{array}{c}.044 \\
(.061)\end{array}$ \\
\hline $3 \mathrm{AM}-4 \mathrm{AM}$ & $\begin{array}{c}.058 \\
(.075)\end{array}$ & $\begin{array}{c}.051 \\
(.072)\end{array}$ & $\begin{array}{c}.098 \\
(.100)\end{array}$ & $\begin{array}{l}.067 \\
(.106)\end{array}$ & $\begin{array}{l}.047 \\
(.053)\end{array}$ & $\begin{array}{c}.041 \\
(.052)\end{array}$ & $\begin{array}{c}.071 \\
(.062)\end{array}$ & $\begin{array}{c}.046 \\
(.055)\end{array}$ \\
\hline 4AM-5AM & $\begin{array}{c}.060 \\
(.077)\end{array}$ & $\begin{array}{c}.054 \\
(.074)\end{array}$ & $\begin{array}{c}.084 \\
(.096)\end{array}$ & $\begin{array}{c}.071 \\
(.113)\end{array}$ & $\begin{array}{c}.047 \\
(.054)\end{array}$ & $\begin{array}{c}.041 \\
(.052)\end{array}$ & $\begin{array}{c}.069 \\
(.066)\end{array}$ & $\begin{array}{c}.048 \\
(.061)\end{array}$ \\
\hline $5 \mathrm{AM}-6 \mathrm{AM}$ & $\begin{array}{l}.073 \\
(.088)\end{array}$ & $\begin{array}{l}.067 \\
(.085)\end{array}$ & $\begin{array}{l}.098 \\
(.112)\end{array}$ & $\begin{array}{c}.079 \\
(.125)\end{array}$ & $\begin{array}{l}.050 \\
(.058)\end{array}$ & $\begin{array}{c}.043 \\
(.057)\end{array}$ & $\begin{array}{c}.072 \\
(.070)\end{array}$ & $\begin{array}{c}.066 \\
(.061)\end{array}$ \\
\hline $\mathbf{N}$ & 12837 & 11044 & 1128 & 665 & 12064 & 9967 & 1476 & 621 \\
\hline \multicolumn{9}{|l|}{$\begin{array}{l}\text { Injury } \\
\text { Characteristics }\end{array}$} \\
\hline $\begin{array}{l}\text { Injury Rate/100 } \\
\text { Employees }\end{array}$ & $\begin{array}{c}4.61 \\
(4.54)\end{array}$ & $\begin{array}{c}4.58 \\
(4.50)\end{array}$ & $\begin{array}{c}4.90 \\
(4.86)\end{array}$ & $\begin{array}{c}4.60 \\
(4.76)\end{array}$ & $\begin{array}{c}3.43 \\
(3.36)\end{array}$ & $\begin{array}{c}3.39 \\
(3.30)\end{array}$ & $\begin{array}{c}3.83 \\
(3.71)\end{array}$ & $\begin{array}{c}3.34 \\
(3.74)\end{array}$ \\
\hline $\begin{array}{l}\text { Injury Duration } \\
\text { in Days }\end{array}$ & $\begin{array}{c}19.32 \\
(19.03)\end{array}$ & $\begin{array}{c}19.31 \\
(19.04)\end{array}$ & $\begin{array}{c}19.41 \\
(19.00)\end{array}$ & $\begin{array}{c}19.41 \\
(18.95)\end{array}$ & $\begin{array}{l}18.16 \\
(18.03)\end{array}$ & $\begin{array}{l}18.16 \\
(18.05)\end{array}$ & $\begin{array}{c}18.15 \\
(17.92)\end{array}$ & $\begin{array}{l}18.16 \\
(17.93)\end{array}$ \\
\hline $\mathrm{N}$ & 25278 & 22312 & 2062 & 904 & 23344 & 19965 & 2529 & 850 \\
\hline
\end{tabular}

- A high percentage immigrant MSA has over 10 percent immigrants; a low percentage immigrant MSA has $\leq 10$ percent immigrants. 
Among native nonhispanic white men there is a bit of evidence that otherwise identical individuals are less likely to be working in the evenings and at night if they reside in metropolitan areas with a large concentration of immigrants, as we saw in the means in top panel of Table 7. All of the effects are negative, but few approach statistical significance. Among women, regardless of ethnicity, we find that the propensity to work evening or night hours is lower, although never significantly so, in metropolitan areas where immigrants form a larger part of the labor force. ${ }^{14}$

The results of estimating regressions like those in Table 4, but also including the immigrant percentage in the area, are presented in the bottom panel of Table 8. Adjusting for demographic factors changes the inferences we drew from the bottom panel of Table 7: Other things equal, we now see that where immigrants are more heavily concentrated natives work in industries where the incidence of injuries is lower, but where the duration of lost workday injuries is longer. Like the results on the timing of work, no strong picture emerges of consistent differences in outcomes between natives distinguished by the concentration of immigrants in the labor markets.

One possibility is that the results in Table 8 mask a threshold effect, with the large impacts of immigrants on natives' amenities becoming visible only when immigrants account for a sufficiently large fraction of the labor force. Nearly 20 percent of the metropolitan U.S. work force lives in areas where immigrants account for over 20 percent of the labor force, and it is perhaps these areas where natives experience the most severe effects of the immigrants' presence. To examine this explanation I added a quadratic in IMMPCT to the probits and regressions in Table 8. The quadratic terms in the probits on work timing were generally insignificant. Some of the quadratic terms in the regressions on injury characteristics were significant, although their inclusion did not change the conclusions of 
Table 8. Effects of the Percentage Immigrant Population in the MSA on Natives' Work Timing and Injury Outcomes, May, June 1991 CPS-

\section{Men}

Working at:

8PM-9PM

9PM-10PM

10PM-11PM

1PM-Midnight

$-.027$

(.031)

Midnight-1 AM

$$
-.025
$$

1AM-2AM

2AM-3AM

AM-4AM

AM-5AM

SAM-6AM

$$
\begin{array}{r}
. .015 \\
(.025)
\end{array}
$$

$$
-.012
$$$$
\text { (.024) }
$$

$$
-.018
$$$$
\text { (.023) }
$$

$$
-.014
$$

(.024)

$\begin{array}{ll}.017 & -.009 \\ (.027) & (.031)\end{array}$

Black Hispanic White

$$
-.043
$$$$
\text { (.045) }
$$

$$
-.102
$$$$
\text { (.140) }
$$

$$
-.176
$$$$
\text { (.137) }
$$

$-.075 \quad-.167$

(.134) (.134)

(.042)

$.090 \quad-.213$

(.123) (.125)

(.038)

$.141 \quad-.012$

(.113) (.114)

(.036)

$.043 \quad-.008$

(.101)

(.102)

$\begin{array}{ll}.031 & .023 \\ (.094) & (.099)\end{array}$

$-.046$

(.028)

$-.031$

(.027)

$.042 \quad-.053$

(.093) (.092)

$-.043$

(.027)

$.043 \quad-.004$

(.092) (.089)

$\begin{array}{cc}.072 & .001 \\ (.084) & (.092)\end{array}$

$\begin{array}{lr}.115 & .035 \\ (.094) & (.097)\end{array}$

Women

All Nonhispanic Black Hispanic White

$\begin{array}{llll}-.068 & -.023 & -.051 & -.153 \\ (.038) & (.045) & (.102) & (.100) \\ -.051 & -.018 & -.068 & -.120 \\ (.035) & (.041) & (.097) & (.094) \\ & & & \\ -.033 & -.012 & -.049 & -.070 \\ (.030) & (.035) & (.093) & (.083)\end{array}$

$\begin{array}{llll}-.034 & -.030 & -.005 & -.099\end{array}$

$\begin{array}{llll}(.026) & (.030) & (.078) & (.064)\end{array}$

$\begin{array}{llll}-.028 & -.030 & -.046 & -.050\end{array}$

$\begin{array}{llll}(.020) & (.023) & (.069) & (.055)\end{array}$

$\begin{array}{llll}-.023 & -.030 & -.013 & -.050\end{array}$

$\begin{array}{llll}(.018) & (.020) & (.064) & (.053)\end{array}$

$\begin{array}{llll}-.020 & -.026 & -.023 & -.025\end{array}$

$(.017) \quad(.019) \quad(.061) \quad(.051)$

$\begin{array}{llll}-.016 & -.027 & -.010 & -.004\end{array}$

$\begin{array}{llll}(.016) & (.019) \quad(.057) \quad(.048)\end{array}$

$\begin{array}{llll}-.015 & -.016 & -.012 & -.058\end{array}$

$\begin{array}{llll}(.017) \quad(.019) \quad(.060) & (.058)\end{array}$

$\begin{array}{cccc}.000 & -.016 & .036 & .045 \\ (.019) & (.022) & (.063) & (.071)\end{array}$

Injury

Characteristics

$\begin{array}{ccccccccc}\text { Injury Rate/100 } & -1.83 & -1.72 & -2.50 & -1.81 & -1.05 & -.90 & -.52 & -3.34 \\ \text { Employees } & (.74) & (.77) & (1.26) & (.95) & (.43) & (.42) & (.64) & (1.05) \\ \begin{array}{c}\text { Injury Duration } \\ \text { in Days }\end{array} & 1.29 & 1.03 & 2.65 & 1.62 & .93 & .87 & 1.32 & .03 \\ & (.81) & (.78) & (1.44) & (1.51) & (.59) & (.56) & (.96) & (1.56)\end{array}$

- Other variables included in the probits are the same as those included in the probits in Table 2. Other variables included in the regressions on injury outcomes are the same as those included in Table 4 . The standard errors on the coefficients in the injury regressions are robust to the clustering of observations within three-and fourdigit industtries. 
generally lower incidence, but longer duration of injuries where immigration had been more prevalent. $^{15}$

\section{Conclusions, and Implications for Job Competition}

Throughout American history the possibility that immigrants "take jobs away from natives" has probably been the biggest spur to nativist sentiment. Economists have addressed this issue during the last twenty years directly by treating immigrants and natives as separate inputs into production and measuring the extent to which they are substitutes, or indirectly by examining how natives' wages or earnings are related to the presence of immigrants. The results of the now myriad studies using these approaches are somewhat conflicting. Here I take an alternative tack, asking whether the preconditions for the absence of direct labor-market competition exist in the form of immigrants' willingness to accept working conditions, and thus find jobs, in fields where jobs would otherwise not exist. To the extent that immigrants will take jobs that natives refuse to accept, one might conclude that they and native workers might be noncompeting groups in American labor markets, with any substitution between them coming only through product-market competition between firms using native labor and those using immigrants.

I interpret the preconditions as implying that immigrants will accept a job that has amenities inferior to one that an otherwise identical native would accept. I examine objective data from the Current Population Survey of May 1991 describing the timing of work over the day, and the June 1991 CPS data (which contained information on immigrant status) linked to industry workplace injury rates and duration. I also examine this possibility using a variety of subjective responses about job amenities in the Quality of American Life surveys conducted in 1971 and 1978. There is at most only very weak evidence of any difference between immigrants and natives generally in the amenities 
associated with the jobs they hold, given the observable characteristics that they bring to the labor market. It thus seems fair to conclude that the preconditions for the absence of direct labor-market competition between immigrants and natives do not exist. Despite occasional anecdotal evidence, along a variety of nonwage outcomes I find no evidence that immigrants in general are willing to "take jobs that [observationally identical] natives don't want."

The one group that differs from the others is African-Americans. They are more likely to work at distinctly inferior times (evenings and nights) than are immigrants or other natives; they work in industries where the risk of injury is greater, and the duration of injuries is longer; and they are less likely to report a variety of job amenities than are members of other groups of native workers. If anything, therefore, the results of this study suggest that African-Americans, possibly because they choose freely, possibly because of residual segregation and discrimination, appear to take jobs that otherwise similar native whites and Hispanics, and immigrants too, are unwilling to take. 


\section{REFERENCES}

George Borjas, “The Intergenerational Mobility of Immigrants," Journal of Labor Economics, 11 (January 1993): 113-35.

Economics, 13 (1995): 201-45.

----, Richard Freeman and Lawrence Katz, "Searching for the Effect of Immigration on the Labor Market," American Economic Association, Papers and Proceedings, 86 (May 1996): 24651.

Charles Brown, "Equalizing Differences in the Labor Market," Quarterly Journal of Economics, 94 (February 1980): 113-34.

Stephen Castles and Godula Kosack, Immigrant Workers and Class Structure in Western Europe. London: Oxford, 1973.

John Haisken-De New and Klaus Zimmermann, "Wage and Mobility Effects of Trade and Migration," Centre for Economic Policy Research, Discussion Paper No. 1318, 1996.

Daniel Hamermesh, Labor Demand. Princeton, NJ: Princeton, 1993.

, "The Timing of Work Time over Time," National Bureau of Economic Research, Working Paper No. 5855, 1996, a.

---------, Workdays. Workhours. Work Schedules: Evidence for the United States and Germany. Kalamazoo, MI: The W.E. Upjohn Institute, 1996, b.

and John Wolfe, "Compensating Wage Differentials and the Duration of Wage Loss," Journal of Labor Economics, 8 (1990): S175-97.

James Heckman and Guilherme Sedlacek, "Heterogeneity, Aggregation, and Market Wage Functions: An Empirical Model of Self-Selection in the Labor Market," Journal of Political Economy, 93 (1985): 1077-1125.

Michael Piore, Birds of Passage. Cambridge, England: Cambridge, 1979.

Cordelia Reimers, "Unskilled Immigration and Changes in the Wage Distributions of MexicanAmerican, Black and Non-Hispanic White Male Dropouts," this volume.

Frank Stafford, "Firm Size, Workplace Public Goods, and Worker Welfare," in John Siegfried, ed., The Economics of Firm Size, Market Structure and Social Performance. Washington: Federal Trade Commission, 1980. 
United States, Department of Labor, Bureau of Labor Statistics, Occupational Injuries and Illnesses in the United States by Industry, 1988, Bulletin 2366. Washington: GPO, 1990. 


\section{FOOTNOTES}

\section{New York Times, March 24, 1996, p. 3.}

2. See Heckman and Sedlacek (1985) for an approach that aggregates workers based on the skills that they implicitly bring to the labor market.

3. The model could be expanded to included immigrants with skills different from those of natives, but that extra complexity would add nothing to the illustration of the mechanisms discussed here.

4. See Stafford (1980) for a very perceptive discussion of the problems of discriminating among workers in the provision of workplace amenities.

5. Only workers with at least 20 hours per week on their main job are included in this sample, so that we can be sure that work at night means presence at work on at least three days per week. The self-employed are excluded from this study.

6. Immigrants constituted 0.3 percentage points fewer of the discarded observations than they did of the observations included in the analysis. This tiny difference suggests that the industries on which the data could not be merged are not particularly immigrant- or native-labor intensive.

7. The hourly wage is calculated as the mid-point of the bracketed annual earnings divided by $52^{*}$ weekly hours. For the highest category I use 1.5 times the lower bound of the categorized annual earnings.

8. In defining the immigrant population in this sample those (very few) people who were born abroad, but whose parents were both Americans, are included as natives even if they indicated that they were immigrants.

9. While I do adjust for detailed industry in the bottom half of this Table, it is interesting to examine whether excluding agriculture, where evening work is difficult, affects the results. Also, the data report usual work schedules on the main job, so that they may be generating a false impression if immigrants' propensities to take second jobs differ from those of natives. The probits in the top half of the Table were thus reestimated excluding the roughly 9 percent of the male sample and 5 percent of the female sample who worked in agriculture or who held more than one job. The results changed only slightly, with immigrants generally working at these hours in the same proportion as natives, and with African-Americans being more likely to be at work at these times.

10. These conclusions are based on a comparison to the results of probits identical to those of Table 2, but estimated only over those workers on whom wage data were available. Workers whose hourly earnings were below $\$ 2.75$ in 1991 were excluded from both of these sets of probits, since it is likely that their hours or weekly earnings were reported incorrectly.

11. One possibility is that establishments employing unusually high proportions of immigrants are more likely to underreport injuries. While this is possible, the quality of the injury data was much higher by 1991 after nearly 20 years of detailed surveys than it had been earlier. Also, these are lost-workday injuries, about which employees are probably quite aware and which are more difficult to hide from statistical surveys than the mere presence of potentially dangerous working conditions.

12. Individuals whose calculated hourly earnings were below $\$ 1$ or above $\$ 100$ (1971 dollars) per hour are excluded from the probits.

13. This is consistent with Borjas' (1993) evidence of substantial, but by no means complete regression of immigrants' earnings toward population averages over one generation. 
14. This result is also not due to the exclusion of detailed measures of workers' industrial affiliation. When least-squares estimates like those in the bottom panel of Table 2 are estimated on the same samples, and with the same other variables, as in Table 8, the coefficients on IMMPCT change only slightly. Nor is it due to interarea differences in unemployment rates. When published unemployment rates by area are interacted with the indicator for immigrant status (and also included as a main effect), no significant changes in the basic results are produced.

15. In another approach along these lines I replaced IMMPCT by a vector of indicator variables corresponding to a categorization of the percentage of immigrants in an area's work force. The results in that case too gave little indication of consistent nonlinearities in the relationship between the presence of immigrants in the work force and the propensities to work evenings or nights, or injury outcomes. 